\title{
Mordedura de Loxoceles en cara
}

\section{Loxosceles bite in face}

Ciro Maguiña ${ }^{1 ; 2, a}$, Raúl Acosta $^{1}$
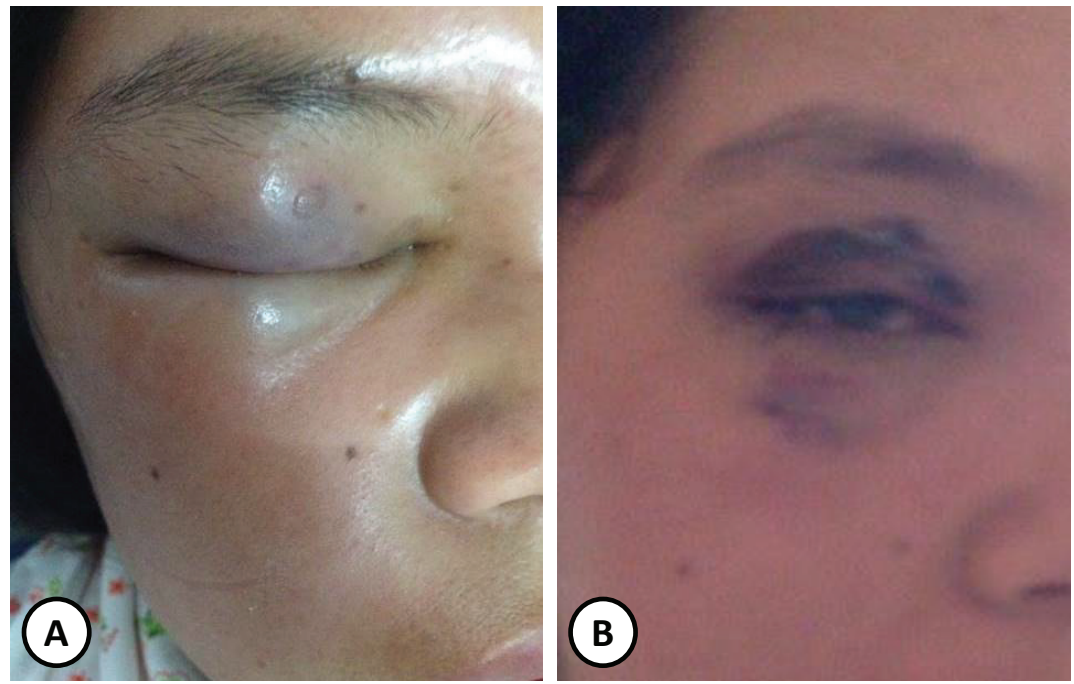

Mujer de 20 años, acudió a emergencia con historia de siete horas de enfermedad. Sintió una picadura en cara de "un insecto que no vio"; a las dos horas notó edema de párpados bilateral que progresa rápidamente a los labios y cara. Al examen se observó lesión pálida violácea en el párpado derecho (A) y edema facial a predominio derecho. Recibió terapia como loxoscelismo severo complicado con suero antiloxosceles, hidrocortisona, clorfeniramina, clindamicina y oxacilina. En la evolución presentó edema de glotis y dificultad respiratoria que requirió intubación endotraqueal. B: Muestra la lesión a los diez días después del alta.

20 year old woman went to emergency with seven-hour history of disease. She felt a sting in the face of "an insect that saw"; two hours he noticed bilateral eyelid edema and rapidly progressing to lips and face. On examination, pale violet lesion was observed in the right eye (A) and facial edema predominantly right. She received therapy as complicated severe loxoscelism with antiloxosceles serum, hydrocortisone, chlorpheniramine, clindamycin and oxacillin. In the evolution she presented glottis edema and respiratory distress requiring endotracheal intubation. B: Shows the injury ten days after discharge.

\footnotetext{
Hospital Cayetano Heredia. Lima, Perú.

Facultad de Medicina. Universidad Peruana Cayetano Heredia. Lima, Perú.

a Profesor Principal. Vicerrector de Investigación.
} 